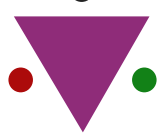

IJCRR

Section: Healthcare

Sci. Journal Impact

Factor: $6.1(2018)$

ICV: 90.90 (2018)

(c) (i) (9)

Copyright@IJCRR

\title{
Possible Management Options for Manoswasthya in Ayurveda
}

\section{Sunita Gupta ${ }^{1}$, Jancy Josheph ${ }^{2}$, Vinayak Shegaonkar ${ }^{3}$}

'Assistant Professor, BAMS-MD (Rog Nidan \& Vikrati Vigyan), DMAMCH \& RC, Hingana, Nagpur, lndia; ${ }^{2}$ MSc in Yogic Science, DMAMCH \&

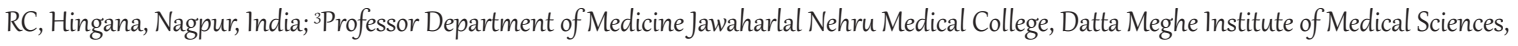
Sawangi (Meghe), Wardha, India.

\section{ABSTRACT}

Ayurveda explains Manoswasthya in-depth \& in a broad manner with the help of Yoga, Aahar \& Sadvrittas. All these concepts of Manoswasthya play an important role to keep \& maintain strong mental health. Mental Health is also an important subject like physical health. The clutches of numberless psychosomatic diseases due to stress. Ayurveda describes in a wide-ranging manner for keeping healthy manna that has been described in two ways - i) by explaining manovighat in diseases \& ii) by explaining the maintenance of manoswathya in daily routine. Prasanna Means because of happiness of manna our soul gets strength \& a person with prasannamanna can do every work with concentration, full efficiency \& by using abilities. By doing such work, a person can solve many problems by giving suggestions to himself as well as others. Ayurveda explains Manoswasthya in-depth \& in a broad manner with the help of Yoga, Aahar and Sadvrittas.

Key Words: Mental Health, Healthy Mind, Yoga, Aahar \& Sadvritas.

\section{INTRODUCTION}

The enormous development in Science and Technology has provided man with every possible comforts and luxury in life. The world has reduced to a global village as a result of the revolution in the field of satellite communications and supersonic aviation. As a result today man is busy with providing as much as comforts as possible to make him happy. ${ }^{1}$ But surprisingly, man is more unhappy and uneasy today with no peace in life. The most alarming fact is that today, man more than ever, is in the clutches of numberless psychosomatic diseases due to stress resulting in strain. ${ }^{2}$

To better understand Manoswasthya and Ayurveda, we should understand the definition of Healthy Mind \& Mental Health.

A Healthy Mind can be defined based on its following characteristics:

1. A happy and contentment state of mind, cheerful disposition and pleasing manners,

2. Feeling of security,

3. Self-esteem and self-confidence.

4. Absence of Tensions \& Frustration,
5. Ability to accept and give love, affection and happiness.

6. Insight or knowledge of self-ability to apply one's capacity to the task at hand.

7. Intelligence and good memory

8. Creative Ability.

9. Perfect control over one's desires, instincts, emotions, behaviour, actions and speech.

10. Stability of mind which does not fluctuate or waver.

11. Truthful speech, clear thought and correct actions.

12. Well-wisher of people and works the uplift of society.

\section{MENTAL HEALTH}

Mental Health is also an important subject like physical health because various mental diseases are rising due to unawareness about mental health, These are like, i) Anxiety, ii) Panic Attacks, iii) Depression, iv) OCD (Obsessive Compulsive Disorder) etc. These are discussed below:

Anxiety: These sweat palms before an exam starts. The beating heart on the stage is characteristic of anxiety. Without early intervention, some anxiety cases can be chronic, but many people especially men feel that seeking help is a sign

\section{Corresponding Author:}

Dr. Sunita Gupta, Assistant Professor, BAMS-MD (Rog Nidan \& Vikrati Vigyan), DMAMCH \& RC, Hingana, Nagpur, India.

ISSN: 2231-2196 (Print)

Received: 20.07 .2020
ISSN: $0975-5241$ (Online)

Revised: 19.09 .2020
Accepted: 14.11 .2020 
of weakness. This is true for nearly all anxiety or mental health problems. Experts believe that some of the faults lie in our culture in which men are not supposed to be fearful. Men buy into this myth themselves, say, psychologists. They will insist that it is a medical condition, like a cardiac arrest, even after that's been ruled out. The fact is, with true panic, the experience in the body feels almost the same as heart attack. ${ }^{3}$

Depression: Depression is a medical illness \& not just a feeling of hopelessness. It's more than just feeling sad. Every $3^{\text {rd }}$ female and every $5^{\text {th }}$ male will have it at least once. Depression is the third most common illness in the world. ${ }^{4}$

According to modern science, behavioural therapy is an important \& parallel treatment to medication. The important thing is to reach out to people coping with such ills, say psychologists so that they can control the symptoms, rather than the symptoms controlling them. So like as "Sadvrittas" is also a type of treatment.

\section{MANOSWASTHA AND AYURVEDA}

Three major concepts of Manoswastha \& Ayurveda are Yoga, Aahar \& Sadvrittas. These are discussed below :

Ayurveda is not only the science which cures the diseases like other pathies (Allopathy or Homeopathy etc.) rather from the point of view of socialization, Acharya's have given several high thoughts or 'updesh' to strengthen the will power \& enhance the moral values of the human being.

The importance of manna has been described in many places like satva pariksha is also included Dasvidha Pariksha, the medicines should be given by keeping in mind the three state of manna i.e. pravare, madhya \& avara. Hence, there should not be any panic of manna, as a result of which the safety of manna will become the safety of manoswasthya or mental health. ${ }^{5,6}$

- Ayurveda describes broadly for keeping healthy manna that has been described in two ways - i) by explaining manovighat in diseases \& ii) by explaining the maintenance of manoswathya in daily routine. The manovighat is also a cause of diseases like Chardi, Atisar, murcha, unmad, Apasmar etc. The Acharyas have indicated that we should keep safety so that there should not be any vighat to manna.

- "Vishado Rogvardhnanaam Shrestham" Vishada is the main cause for the rising the disease. The sadness of manna, poor will power, creates the negative thoughts in the manna, as a result of which the disease widens $\&$ on the other hand, if there is positive thinking $\&$ high will power, one can get rid of uncurable diseases too. There is also a lokokti- 'manna ke hare har hai manna ke jite jit. ${ }^{6}$
Thus for keeping healthy manna, we should follow the rules of Ayurveda by accepting the Dinacharya, Ritucharya \& Sadvrittas in our daily routine.

- In the present scenario, everyone has become so much luxurious life stylish, greedy for money, greedy for high-level jobs. To fulfil such aims, by keeping aside the manna, peoples apply any means which may be wrong but because of Asatmyaindriyartha Samyoga, they are facing many complicated diseases. A man can avoid anything except his manna. The crimes which he does, give him so many pains in the loneliness that he becomes a patient of depression.?

- On the other hand for keeping healthy manna Acharyas have given the ideas of Yoga, Aahar \& Sadvrittas.

\section{DISCUSSION}

Yoga is a system of living with sense and science of the realisation of ultimate values and altruistic mission of life. Yoga evolves a harmonious order in mind, matter and men. Yoga practices are used for the therapy Asanas, Kriyas, Pranayams, Bhandas, Mudras and Meditation techniques are all used for the treatment of psychosomatic diseases. Through the practice of Yoga, we can acquire physical \& mental health. The Yoga includes eight steps Yama, Niyama, Aasana, Pranayama, pratyahar, Dharna, Dhayan, and Samadhi. Every step is very important for keeping healthy manna but Pranayama has become so much popular \& useful that the whole universe has accepted the importance of pranayama. By Pranayama the body, mind \& manna go on the right path. ${ }^{7,8}$

The eight steps of Yoga are discussed below:

- Yama: Yama means self-control. Patanjali explains Yama as Ahinsa, Stalya, Asteya, Brahmacharya, and Aparigrah Yama. This purifies the mind \& Chitta. In this way manna becomes healthy.

- Niyama: Niyama means discipline or following the rules of good conduct. Niyama - "Soch Santosha Tapan Svadhyaya Isvarapranidhanani niyamah" means internal \& external purification.

- Asana: "Sthiram Sukham Asanam" which means the posture is that which is firm and pleasant without a firm seat one cannot sit for a long time \& cannot concentrate too.

- Pranayama: The Chitta has, by its nature, all knowledge. It is made up of satva particles but is covered by rajas \& tamas particles, and pranayam removes this covering and mind becomes fit for concentration. In this way Mann becomes healthy.

- Pratyahara: By practising this, the aspirant can keep his mind undisturbed by worldly objects.

- Dharna: is the concentration of Chitta on some objects.

- Dhyana \& Samadhi: Meditation is a proved \& successful cause for Manoswasthya. 
The knowledge about all Yoga and its eight steps will be helpful to understand the subject as to how they keep healthy manna. Further, the referred eight steps of Yoga make the manna pure \& healthy. ${ }^{4-6}$

For the development of mind, three courses are to be followed - wholesome food, congenial atmosphere \& regular exercise. With the help of following food rules in Ayurveda, the relationship of Manna \& Aahar can be discussed as under:

उष्ण्, स्नग्धिं मात्रावत्, जीर्णे, वीरयावरुध्म्, इष्टेशे,इष्टसरवोपकरण्,नातद्रित्रत्, नातविलिम्बतिं, अजल्पन्त, तन्मना भुन्जीत,आत्मानमाभसिमीक्ष्य सम्यक्।च्.वा.१/२४

- The food should be ushna, snigdha \& matravad,

- It should be taken after digestion of previous food,

- It should be virya-aviruddham,

- The place \& contents of food should be as desired by the user,

- It should be taken on the right time,

- The food should be peaceful by avoiding talking \& laughing while taking the same and

- The quantity of food should be as per the user's capacity.

By following the above rules, we can avoid manovighat. Food which we take, one part of it nourishes our manna too and in the reference of rasa karma we find that :

- Madhur Rasa - keeps happy to all five indriyas with manna,

- Amal Rasa - activates our manna,

- Katurasa - activates all indriyas for doing their work.

\section{APPLICATION OF SADVRITTA}

Acharyas have stressed on the point that we should never take food on that place or in that situation which deviate our 'manna' so that manna will be happy, 'swastha \& will keep indriyas with proper connection to their subject or samyak yoga. This is also said that for the proper digestion of food the happiness of manna is necessary. In spite of good quality \& proper quantity, food can not be digested if there is chintya, shock, bhaya, krodha, dukha \& jagrana. From the above, it is clear that Manna \& Aahar (food) are related to each other. The last but most important concept is "sadvrittas". Sadvritta means to follow the good behaviour and as to why we should follow the same has been explained by Acharyas as under:-

\section{तस्मादात्महतिं चकिर्ष्तीता सर्वेन् सर्वं सर्वदा स्म्रतमिस्थाय सद्व्रत्त्मानुष्ठठयम्॥च्. सू.८/१७}

For self-help, everyone should follow all the Sadvrittas sincerely by keeping in mind that by following the Sadvrittas we can get two things simultaneously - Arogya \& Vijaya on Indriyas. The complete description of the Sadvrittas is given below:-

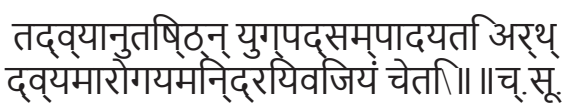

Worship of Devta, Gow, Brahmin, Vridha, Sidha purush \& Acharyas, Agni-Upasna, using good medicines \& taking bath both the times. By all these activities we get strength \& our manna becomes happy, the concentration of mind \& when the day begins with good activities \& feelings, the whole day will also be good \& manna will be full of energy.

We should not waste our working time, we should not start any new work without examining the same, should not be in the control of indriyas, should not take more tension which may cause bad effects on our mind, should not be lazy, should not be in the control of grief, should not be much happy on being a success and unhappy on failure, should not forget rules of nature phrased as "As you sow, so you reap", should not be much hope for the efforts made.

Application of Sadvrittas is the best way to have healthy manna.

- We should have good self-control on the excitement of our manna.

- We should not be in the control of grief - If we have much tension there may be many mental disorders because of manovighat.

- We should not forget the rule of nature -"As you sow, so you reap". Here, Acharyas want to say that there should be a feeling of fear while doing the bad works because we have to bear the result of every work whether good or bed. Hence, we should do good works only so that there will not be manovighat.

- We should not be much hopeful from every effort made. We should not be depressed on failure even after doing the hard work. For example, for various competitive exams, several intelligent students do the hard work \& become much hope for success but on being a failure, they go in depression and lose their all capabilities and even attempt to commit suicide. If they don't become much hopeful $\&$ accept the result of whether success or failure, they will be able to analyse their efforts to know their weakness.

- We should not always keep in mind the misbehaviour done by anybody intentionally or otherwise. So, we will not have feelings of ego \& revenge and manna will be healthy. As a result, a person will be able to do his work with concentration \& get the success easily.

\section{CONCLUSION}

Happiness of manna our soul gets strength and a person with prasannamanna can do every work with concentration, full efficiency $\&$ by using abilities. By doing such work, a person can solve many problems by giving suggestions to himself 
as well as others. Ayurveda explains Manoswasthya in-depth and a broad manner with the help of Yoga, Aahar \& Sadvrittas.

\section{ACKNOWLEDGMENT}

Authors acknowledge the immense help received from the scholars whose articles are cited and included in references to this manuscript. The authors are also grateful to authors / editors / publishers of all those articles, journals, and books from which the literature for this article has been reviewed and discussed.

Ethical clearance- Taken from the institutional ethics committee.

Source of funding- Self.

Conflict of Interest- Nil.

\section{REFERENCES}

1. Yadav T. Charak Samhita of Agnivesha elaborated by Charak and Dridbala with Ayurved Dipika, published by, Chaukhamba Sanskrit Sansthan, Varanashi $11^{\text {th }} \mathrm{Ed}^{\text {n }}, 2000$.
2. Astang Sangrah of Vrddha Vaghbhata with Shashilekha Sanskrit Commentary by Indu, published by Chaukhamba Series Office, Varanashi $3^{\text {rd }}$ Ed $^{\mathrm{n}} 2012$.

3. Susruta Samhita of Maharsi Susruta edited with Ayured-TatvaSandipika Hindi Commentary by Kaviraj Ambikadutta Shastri published by Chaukhamba Sanskrit Sansthan, Varanashi $11^{\text {th }}$ $\mathrm{Ed}^{\mathrm{n}}, 1997$.

4. Thakaral K. Sushruta, Sushrut Samhita with Nibandhasangraha Commentary of Dalhana \& Nyayachandrika Commentary of Gayadasa Vol II, Reprint. Varanasi, U.P: Chaukhamba Orientalia; 2014; 187.

5. Mishra S. Ayurvediya Rasashastra, 4th edition. Varanasi, U.P. Chaukhamba Orientalia; 1993;435.

6. Vuolo J. Hypergranulation: exploring possible management options. British Journal of Nursing. 2010; 19(6):S4-8.

7. Sharma P. Dravyaguna Vijnana Vol II, Reprint. Varanasi, U.P: Chaukhamba Bharati Academy; 2003;179-80.

8. Yadav T. Sushruta, Sushrut Samhita with Nibandhasangraha Commentary of Dalhana \& Nyayachandrika 'Kavyatirth'. Reprint. Varanasi, U.P: Chaukhamba Surbharti Prakashana; 2008; 397. 